\title{
Remainers are nostalgic too: an exploration of attitudes towards the past and Brexit preferences
}

\author{
Abstract \\ Nostalgia had a prominent place in the Brexit Referendum campaign, epitomized by Nigel \\ Farage carrying around with him an old-fashioned blue British passport on the campaign trail. \\ In this paper, we seek to examine British attitudes towards the past through a new survey \\ instrument administered online in July and August 2018 (N=3000). We empirically establish \\ two dimensions of nostalgia that are differentially associated with political preferences. We \\ conclude that it is the substance of the nostalgia that matters, not the looking towards the past \\ per se.
}

Key words: Brexit; traditional nostalgia; egalitarian nostalgia; social change, ethnic exclusion

Word count: 2546

\section{Introduction}

The nostalgia of the Brexit Referendum campaign can perhaps be epitomized by Nigel Farage carrying around with him an old-fashioned blue British passport on the campaign trail, described by Otto English in the Independent, 'as a sort of weird "Brexit carrot" to entice people to vote Leave $e^{\prime}$. Nostalgia for the past has also been a central feature of other political campaigns of far-right parties in Europe such as the AfD in Germany, the National Front in France, and the Sweden Democrats (Elgenius and Rydgren 2018). And the nostalgia frame, of course, was central to Trump's 'Let's Make America Great Again'. In the politics of the radical right, nostalgia is offered as an antidote to a decaying present (Kenny 2017); unlike anti-immigration sentiment or xenophobia, the nostalgic frame of ethnic nationalism is relatively free of stigma (Elgenius and Rydgren 2018) thus making it a useful rhetorical tool (Kenny 2017). 
Beyond the political discourse, recent studies and commentaries have invited empathy with those who have been left feeling nostalgic. It is suggested that anti-immigration and Brexit preferences are natural and understandable consequences of feeling lost and left behind in the modern world (E.g. Gaston and Hilhorst 2018; Goodhart 2017; Gest 2016). Evidently then, nostalgia is intertwined with debates about the so called 'left behind', a term coined in the search to explain why so many Britons voted for the UK to leave the European Union in the 2016 referendum. The 'left behind' is a descriptive term with the normative implication that the experienced loss from economic development and globalisation, in relative terms, has been unfair (Jackson and Grusky 2018). From the perspective of the liberal elite, 'left behind' may conjure an image of British citizens who were not just economically marginalised but unable to keep up with social and cultural changes (Kenny 2017). The cultural divide separates those who are more open to immigration with a cosmopolitan outlook (Inglehart and Norris; Bhambra 2017), and those with more traditional and local (non-globalised) views (Goodhart 2017).An alternative perspective can be in sought in Pettigrew and Meertens' (1995) classic paper on subtle versus blatant prejudice which highlights that 'the defence of traditional values' has a racialized nature, namely that 'traditional values' might be in themselves a facet of subtle prejudice.

In this study, we set out to measure preferences for the past of fifty years' ago among a representative sample of British people. There are few quantitative sociological accounts of nostalgia, a gap we seek to fill with the analysis of newly developed measures designed to tap into dimensions of nostalgia.

\section{About this study}

From the Homeric Greek nostos (meaning return home) and algos (pain), nostalgia in its literal meaning is a yearning to return home. In Fred Davis' (1979) Yearning for Yesterday: a Sociology of Nostalgia, nostalgia was considered to be a constructed social memory which draws on the past but is unmistakably a product of the present. His account suggests that nostalgia is 
triggered by 'fears, discontents, anxieties, or uncertainties' and as such could be construed as pessimism about social change (Turner 1987). For Davis, 'nostalgia' should be applied to lived experiences but in this study we apply a wider definition of nostalgia that allows young people as well as old to be nostalgic for a past they have never known. In any case, memories are likely to be selective reconstructions of the past and rooted in affective reactions to the present. Thus, we treat nostalgia as a retrospective lens that distorts the past from the viewpoint of the present.

We choose to root our empirical approach in concrete social change, and avoid loaded terms such as loss or nostalgia. We use data from a single wave of a panel study fielded by Kantar Public in July/August 2018. Respondents were sampled from an access panel with considerable attention to representativeness and efforts made to pull in 'hard to reach' sectors of society. Benchmarking shows that these data perform well on representativeness compared to face-toface surveys. We asked the 3000 respondents: Do you think Britain was a better place to live 50 years ago? The modal answer was 'yes' at $45 \%, 31 \%$ of people said 'no', and the remaining $24 \%$ 'I don't know'. More young people 'didn't know' than older people, perhaps unsurprisingly since this group has fewer lifetime experiences on which to draw. Respondents were then asked: here are some of the things that have changed in the last 50 years. Do you think these aspects of modern life make life worse, or make life better? Respondents indicated whether life was made better, made worse, made no difference, or 'don't know' for eleven different aspects of social change. We selected social changes giving broad coverage (i.e. are not just about immigration and ethnicity) and also that are common knowledge and uncontroversial ${ }^{3}$. The wording of the eleven social change items can be seen in Figure I.

\section{Analysis}

Figure I shows that the majority of British people report that higher levels of economic inequality and the lack of working class politicians make life worse. New ways of communicating (Facebook and Instagram) are also unpopular with 41\% saying these make life 
worse. The items that had the lowest numbers saying 'make life worse' include greater opportunities to go to university, the increase in ethnic minority and female politicians, and more choice in TV and entertainment. On some items, the proportion saying 'makes no difference' is rather high, particularly for the level of church attendance and more open same sex couples. This middle answer option perhaps ought not to be treated as indifference towards the social change but rather as modest acceptance (e.g. 'I don't mind that fewer people go to church these days').

[Figure I here]

\section{Is there more than one underlying type of nostalgia?}

To further explore the structure of nostalgic attitudes we use factor analysis. This reveals two underlying dimensions of nostalgia, shown in Table I. The first we label 'traditional nostalgia', which is characterised by high factor loadings on ethnic diversity, diversity among politicians, and open same-sex couples. The loadings are more moderate for technology, educational opportunities and women working. The second factor we label 'egalitarian nostalgia', which is characterised by high factor loadings on economic inequality and the professionalization of the political class. Note that items with similar loadings on both these latent factors include technology and social media ${ }^{4}$.

[Table I about here]

\section{What kind of people are nostalgic?}

In a multivariate analysis (Table II), we find that age is associated with higher levels of both types of nostalgia ${ }^{5}$. Both types of nostalgia also have an education gradient, which is particularly marked in the case of egalitarian nostalgia. In model 2, when immigration attitudes are controlled, the white British appear to have lower levels of traditional nostalgia, perhaps 
surprising given its ethnic component ${ }^{6}$. Both remain voting and abstention are associated with lower levels of traditional nostalgia, an association that holds even with attitudes to immigration controlled. Respondents preferring to increase or to keep immigration at its current level score substantially lower on traditional nostalgia than respondents wanting immigration to be reduced. Traditional nostalgia is higher among those with higher scores on the authoritarianism scale while Egalitarian nostalgia is lower among those with preferences for right-wing economic policy.

[Table II about here]

\section{Discussion and conclusions}

In contrast to psychological approaches, our definition of nostalgia is attitudinal rather than affective. With this approach, we uncover two types of nostalgia among the British public, which are differentially associated with political preferences. It is the traditional type of nostalgia that is linked to preferences for Brexit whereas egalitarian nostalgia is associated with preferences to remain.

Our derived measure of traditional nostalgia is defined by its relationship to preferences for traditional family forms: for these respondents 'more women working' and 'more open samesex couples' have made life worse. It therefore seems evident that those with high levels of traditional nostalgia are not fully at home in modern Britain. The world they wish for is ethnically homogeneous, with traditional family structures and gender roles, a world long gone and irretrievable. Egalitarian nostalgia is perhaps a more optimistic utopian type (May 2017), being pro-social in its concern with political representation and better economic outcomes for the many.

Both types of nostalgia are associated with older age groups. Young people may have little knowledge of the economic distribution of the past (and no lived experience of lower inequality) and older people, for example with paid-off mortgages and economic stability, may 
not be experiencing the turmoil of the present; however, these results suggest that the older people with high levels of egalitarian nostalgia may be concerned for the experiences and opportunities of younger generations.

The patterns of clustering that define our nostalgia types are familiar patterns of attitudinal clusters; we do not wish to claim that the clusters are new but rather that we must look at the content of the nostalgia in order to understand its link to political preferences. It highlights the need to see nostalgia for what it really is - a social construction reflecting the sentiments that flourish in political discourse - not as a satisfactory justification or explanation of political preferences per se. The danger is, in the same way that 'left behind' is used to legitimise or rationalise the Brexit vote, that nostalgic explanations can see ethnic, gender, and other inequalities discarded from the conversation (Bhambra 2017). To use Bhambra's terms, we must make sure that nostalgia is not 'a euphemism for a racialized identity politics' (S227). Nor indeed should we forget that Remainers are nostalgic too. 


\section{Notes}

${ }^{1}$ https://www.independent.co.uk/voices/vince-cable-brexit-white-nigel-farage-nostalgia-libdem-ukip-immigration-racist-a8251966.html

${ }^{2}$ In fact, we based our choice of items largely on the basis of a recent book on social change by two of the authors (Heath et al. 2018). The majority of the social change items are based on topics for which we have reviewed or complied strong evidence.

${ }^{3} \mathrm{~A}$ third factor, when allowed, relates to technology/ media. It explains little variance (eigenvalue 0.29) thus is not pursued.

${ }^{4}$ We rotate factor loadings using oblique promax. The factors correlate at 0.43 .

${ }^{5}$ We considered that this may be an artefact of including 'Don't Know' in the denominator. However, we replicated models with number of DKs controlled, and our findings hold firm.

${ }^{6}$ Bivariate analysis shows that all minority ethnic groups have lower traditional nostalgia than the white British. Only once other attitudes are controlled do statistically significant differences emerge in the other direction. A reviewer of this paper suggested that marginalised populations may differ in their understandings of nostalgia, and we agree. One avenue for future studies would be to disentangle the effects of religion, ethnicity and experiences of discrimination.

\section{References}

Bhambra, G. K. 2017 Brexit, Trump, and 'methodological whiteness': on the misrecognition of race and class. British journal of sociology, 68, S214-S232.

Davis, F. 1979 Yearning for yesterday: A sociology of nostalgia. Free Press.

Elgenius G and Rydgren J. (2018) Frames of nostalgia and belonging: the resurgence of ethno-nationalism in Sweden. European Societies: 1-20.

Gaston S and Hilhorst S. 2018 At Home in One's Past: Nostalgia as a Cultural and Political Force in Britain, France and Germany. DEMOS, London.

Gest J. 2016 The new minority : white working class politics in an age of immigration and inequality, New York: Oxford University Press.

Goodhart D. 2017 The road to somewhere : the populist revolt and the future of politics, London: Hurst \& Company. 
Heath, A. F., Garratt, E., Kashyap, R., et al. (2018). Social Progress in Britain. Oxford University Press.

Heath, A. F., Richards, L, and Kenny, J. (2020 forthcoming); Brexit Panel; UK Data Archive.

Hobolt SB. 2016 The Brexit vote: a divided nation, a divided continent. Journal of European Public Policy 23: 1259-1277.

Inglehart R and Norris P. 2016 Trump, Brexit, and the rise of populism: Economic have-nots and cultural backlash.

Jackson, M. and Grusky, B.D. 2018. A post-liberal theory of stratification. The British Journal of Sociology, 69(4): 1096-1133.

Kenny M. 2017 Back to the populist future?: understanding nostalgia in contemporary ideological discourse. Journal of Political Ideologies 22: 256-273.

May V. 2017 Belonging from afar: nostalgia, time and memory. The Sociological Review 65: 401-415.

Pettigrew TF and Meertens RW. 1995 Subtle and blatant prejudice in Western Europe. European journal of social psychology 25: 57-75.

Turner BS. 1987 A note on nostalgia. Theory, Culture \& Society 4: 147-156. 


\section{Tables}

Table I - Nostalgia Factor Analysis: Rotated factor loadings

\begin{tabular}{|l|l|l|}
\hline & $\begin{array}{l}\text { Traditional } \\
\text { Factor }\end{array}$ & $\begin{array}{l}\text { Egalitarian } \\
\text { Factor }\end{array}$ \\
\hline Worse: Technology & $\mathbf{0 . 5 0 9}$ & 0.423 \\
\hline Worse: Diverse politicians & $\mathbf{0 . 7 4 0}$ & -0.080 \\
\hline Worse: Social media & 0.478 & 0.459 \\
\hline Worse: TV/ entertainment & $\mathbf{0 . 4 8 9}$ & 0.258 \\
\hline Worse: Education opportunities & $\mathbf{0 . 5 0 6}$ & 0.145 \\
\hline Worse: Women working & $\mathbf{0 . 6 0 9}$ & 0.135 \\
\hline Worse: Ethnic diversity & $\mathbf{0 . 7 0 2}$ & 0.095 \\
\hline Worse: Church/ secularization & $\mathbf{0 . 4 1 9}$ & 0.154 \\
\hline Worse: Economic inequality & -0.112 & $\mathbf{0 . 5 9 1}$ \\
\hline $\begin{array}{l}\text { Worse: Professionalization of } \\
\text { politicians }\end{array}$ & -0.014 & $\mathbf{0 . 6 2 2}$ \\
\hline Worse: Same-sex couples & $\mathbf{0 . 7 1 8}$ & -0.026 \\
\hline
\end{tabular}

NOTES: variables recoded to binary, with Don't Knows retained in denominator. Traditional Factor eigenvalue 1.856; Egalitarian factor eigenvalue 0.600; Scree plot suggests two factors; $N=3002$; KaiserMeyer-Olkin $=0.75$ 
Table II Socio-demographic profiles of the two nostalgias (linear regression coefficients)

\begin{tabular}{|c|c|c|c|c|c|c|}
\hline & \multicolumn{3}{|c|}{ Traditional nostalgia } & \multicolumn{3}{|c|}{ Egalitarian nostalgia } \\
\hline & Model 1 & Model 2 & Model 3 & Model 1 & Model 2 & Model 3 \\
\hline & $\mathrm{b} / \mathrm{se}$ & $\mathrm{b} / \mathrm{se}$ & $\mathrm{b} / \mathrm{se}$ & $\mathrm{b} / \mathrm{se}$ & $\mathrm{b} / \mathrm{se}$ & $\mathrm{b} / \mathrm{se}$ \\
\hline \multirow{2}{*}{ Female } & $-0.118^{* *}$ & $-0.105^{* *}$ & $-0.071+$ & $0.056^{*}$ & $0.061^{*}$ & $0.084^{* *}$ \\
\hline & {$[0.030]$} & [0.028] & [0.038] & [0.024] & [0.024] & [0.032] \\
\hline \multirow[t]{2}{*}{ Age } & $0.010^{* *}$ & $0.007^{* *}$ & $0.008^{* *}$ & $0.010^{* *}$ & $0.008^{* *}$ & $0.010^{* *}$ \\
\hline & {$[0.001]$} & {$[0.001]$} & {$[0.001]$} & [0.001] & [0.001] & {$[0.001]$} \\
\hline \multicolumn{7}{|l|}{ Education ref cat $=$ degree } \\
\hline \multirow[t]{2}{*}{ Other higher education } & $0.244^{* *}$ & $0.183^{* *}$ & 0.062 & $0.113^{* *}$ & $0.125^{* *}$ & $0.091+$ \\
\hline & {$[0.050]$} & {$[0.048]$} & {$[0.066]$} & {$[0.042]$} & {$[0.042]$} & {$[0.055]$} \\
\hline \multirow[t]{2}{*}{ A level etc. } & $0.089^{*}$ & 0.049 & 0.016 & 0.047 & 0.047 & $0.079+$ \\
\hline & {$[0.043]$} & {$[0.041]$} & {$[0.055]$} & {$[0.036]$} & [0.036] & [0.046] \\
\hline \multirow[t]{2}{*}{ GCSE etc. } & $0.168^{* *}$ & $0.079+$ & 0.018 & -0.039 & -0.032 & -0.033 \\
\hline & {$[0.044]$} & {$[0.042]$} & {$[0.056]$} & {$[0.036]$} & [0.037] & {$[0.047]$} \\
\hline \multirow[t]{2}{*}{ Other/ none } & 0.07 & -0.026 & $-0.152+$ & $-0.275^{* *}$ & $-0.261^{* *}$ & $-0.271^{* *}$ \\
\hline & {$[0.069]$} & {$[0.066]$} & [0.088] & [0.057] & [0.058] & {$[0.074]$} \\
\hline \multirow[t]{2}{*}{ White British } & 0.003 & $-0.093^{*}$ & -0.063 & 0.05 & 0.004 & 0.031 \\
\hline & {$[0.047]$} & {$[0.046]$} & {$[0.063]$} & [0.039] & {$[0.040]$} & [0.053] \\
\hline \multicolumn{7}{|l|}{ Class ref cat $=$ Professional } \\
\hline Intermediate occupations & $\begin{array}{c}-0.105^{* *} \\
{[0.038]}\end{array}$ & $\begin{array}{c}-0.125^{* *} \\
{[0.036]}\end{array}$ & $\begin{array}{l}-0.102 * \\
{[0.048]}\end{array}$ & -0.045 & $\begin{array}{l}-0.045 \\
50.0311\end{array}$ & $\begin{array}{l}-0.068+ \\
-0.0401\end{array}$ \\
\hline \multirow[t]{2}{*}{ Semi-routine/ routine } & $-0.128^{*}$ & $-0.175^{* *}$ & $-0.133^{*}$ & -0.006 & -0.01 & -0.058 \\
\hline & {$[0.050]$} & [0.047] & {$[0.066]$} & {$[0.042]$} & [0.042] & [0.055] \\
\hline \multirow[t]{2}{*}{ Other or never worked } & -0.076 & $-0.125^{*}$ & -0.048 & 0.024 & 0.013 & -0.02 \\
\hline & {$[0.058]$} & {$[0.055]$} & {$[0.078]$} & {$[0.048]$} & {$[0.048]$} & [0.065] \\
\hline \multicolumn{7}{|l|}{ Referendum vote ref cat $=$ leave } \\
\hline \multirow[t]{2}{*}{ Remain } & & $-0.300^{* *}$ & $-0.393^{* *}$ & & 0.031 & $-0.065+$ \\
\hline & & [0.034] & [0.044] & & {$[0.030]$} & {$[0.036]$} \\
\hline \multirow[t]{2}{*}{ Did not Vote } & & $-0.215^{* *}$ & $-0.191^{* *}$ & & -0.043 & $-0.144^{* *}$ \\
\hline & & [0.048] & [0.067] & & [0.042] & {$[0.056]$} \\
\hline \multicolumn{7}{|l|}{$\begin{array}{l}\text { Immigration ref cat }=\text { should be } \\
\text { reduced a lot }\end{array}$} \\
\hline \multirow[t]{2}{*}{ Increased/ stay the same } & & $-0.498 * *$ & & & $-0.145^{* *}$ & \\
\hline & & [0.039] & & & [0.034] & \\
\hline \multirow[t]{2}{*}{ Reduced a little } & & $-0.439 * *$ & & & -0.005 & \\
\hline & & {$[0.040]$} & & & [0.035] & \\
\hline \multirow[t]{2}{*}{ Authoritarianism } & & & $0.218^{* *}$ & & & $-0.050 *$ \\
\hline & & & [0.023] & & & [0.019] \\
\hline \multirow{2}{*}{ Right-wing economic preferences } & & & $0.044^{*}$ & & & $-0.187^{* *}$ \\
\hline & & & [0.021] & & & [0.018] \\
\hline \multirow[t]{2}{*}{ Constant } & $-0.474^{* *}$ & $0.347^{* *}$ & -0.014 & $-0.533^{* *}$ & $-0.352^{* *}$ & $-0.449^{* *}$ \\
\hline & [0.095] & {$[0.073]$} & {$[0.093]$} & [0.079] & {$[0.064]$} & [0.077] \\
\hline Adj R-squared & 0.08 & 0.19 & 0.17 & 0.07 & 0.08 & 0.12 \\
\hline $\mathrm{N}$ observations & 3000 & 2933 & 1710 & 3000 & 2933 & 1710 \\
\hline
\end{tabular}

Region controlled but coefficients not reported. Authoritarianism and left-right preferences taken from Wave 4 , hence lower $N .{ }^{*} p<0.05 * * p<0.01$ 